\title{
A REMOTE SENSING AND GIS-BASED MODEL OF HABITAT AS A PREDICTOR OF BIODIVERSITY
}

\author{
DIANE M. DEBINSKI $\uparrow$ DEPARTMENT OF ANIMAL ECOLOGY \\ IOWA STATE UNIVERSITY $\downarrow$ AMES \\ KELLY KINDSCHER $\downarrow$ KANSAS BIOLOGICAL SURVEY \\ UNIVERSITY OF KANSAS $\uparrow$ LAWRENCE
}

\section{$\downarrow \quad$ ABSTRACT}

Conservation biologists need better methods for predicting species diversity. This research investigated some new methods to analyze biodiversity patterns through the use of Geographic Information Systems and remote sensing technologies. We tested the correlation between remotely sensed habitat types and species distributions. The goal was not to do away with ground-based fieldwork, but rather to optimize and focus fieldwork by using GIS and remotely sensed data as tools for making the work more accurate and specific. Our research was conducted at a fine $(30 x$ $30 \mathrm{~m}$ ) landscape scale using on-the ground locations of birds, butterflies, and plants in the northwest portion of the Greater Yellowstone Ecosystem. Three remotely sensed forest types (distinguished by species density and coverage) and six remotely sensed meadow types (ranging from xeric to hydric) were surveyed and coverage data were collected for grasses, shrubs, forbs and trees. Presence/absence data were collected for birds and butterflies. The objectives of this research were: 1) to determine the extent of the correlation between spectral reflectance patterns and plant or animal species distribution patterns, and 2) to test the spatial correspondence of species diversity "hotspots" among taxonomic groups. Field surveys in 1993 and 1994 validated the vegetation density, cover, and moisture gradients expected from satellite data interpretation. Both tree
\end{abstract}

species composition and diameter at breast height were significant in discriminating among forest types. Twenty-two species of grasses and forbs were significant in distinguishing among meadow types. However, a smaller percentage of the animal species was significantly correlated with one habitat type. In order to find a strong correlation between species distribution patterns and remotely sensed data, a species must be moderately common and show some habitat specificity. Hotspots of species diversity coincided for shrubs, grasses, forbs, birds, and butterflies and were found in mesic meadows.

\section{$\uparrow \quad$ INTRODUCTION}

The loss of biodiversity has become a global concern during the last decade (Wilson 1988, Reid and Miller 1989). What conservation biologists need now are better methods to predict species diversity so that areas of high species richness can be protected and rare or declining species identified. The need to predict these areas of high species richness and species of concern is even more pressing as we enter an era of potential global climate change.

Prerequisites to good management of biological diversity are adequate floral and faunal inventories for the lands in question and a firm foundation in community ccology. Biologists are just beginning to grapple with issues of how to assess 
biodiversity and create databases that will be valuable to a wide spectrum of users (Scott et al 1990, Scott et al. 1993, Davis et al. 1990, Noss 1983, Margules and Austin 1991). However, species lists are only a first step in addressing larger questions regarding relationships between species and their environments, in particular, species responses to environmental change. Understanding the environmental parameters that define species distributions is an even more important component of biodiversity assessment.

One of the many possible objectives for terrestrial biodiversity assessments, and a potentially fruitful one, is development of testable hypotheses concerning the relationships between geographic variation in species distribution patterns, and variation in environmental gradients. Vertebrate biologists have been using knowledge of an animal's habitat to predict its presence or absence for decades (e.g., Baker 1956, Armstrong 1972). Many studies have produced testable hypotheses relating variations in terrestrial species associations to inferred or measured variations of physical environmental factors (e.g., Simpson 1964, Owen 1990, Pyle 1982, James 1971, Terborgh 1970, Debinski 1991,1994a, Kindscher 1994, Kindscher 1995). However, scientists are just beginning to use remote sensing data as a predictor of animal species distribution patterns (Scott et al. 1993, De Wulf et al. 1988, Saxon 1983, Tueller 1989, Stoms and Estes 1993).

The emergence of landscape ecology as a discipline has been instrumental in helping scientists understand spatial patterns of species distribution (Turner 1989, Urban et al. 1987, Noss 1983). As these relationships are better understood, it may be possible to predict species diversity based upon landscape level habitat analysis using Geographic Information Systems (GIS) and remotely sensed data (Urban et al. 1987, Turner 1989, McLaughlin et al. 1992, Rich et al. 1992 a,b) at fine-scale resolutions. Conversely, such analyses can help optimize sampling strategies or allow us to test hypotheses regarding the spatial correspondence of species diversity patterns among taxonomic groups (e.g., Prendergast et al. 1993). Although patterns of community structure are produced by a variety of interactions, analysis of the patterns themselves can also prove helpful in broadening our interpretations. For example, Kolasa (1989) used pattern analysis to develop a hierarchical model describing observed patterns of species abundance.

Gap Analysis was developed by the U.S. Fish and Wildlife Service as a technique to compare locations of plant and animal habitats to those of existing preserves, thereby identifying gaps in habitat and/or species protection. Gap Analysis uses LANDSAT Thematic Mapper (TM) imagery to determine boundaries of vegetation types and then incorporates other data to label the vegetation types to series level (Scott et al. 1993). Given the knowledge of the geographical limits of a species' distribution, its ecological limiting factors, and its habitat preferences, species distributions are predicted within a map polygon using county of occurrence data and habitat-association matrices (Scott et al. 1993). Overlays of several species can be used to create a composite map of species richness throughout an area. Many factors besides vegetation type affect species presence and can cloud the observed relationship between species and vegetation (Flather et al. 1995). Even if a habitat appears suitable, the species of interest may not be present due to historical factors, interspecific interactions, or factors extrinsic to the specific site. Another problem with Gap Analysis is the scale at which it is conducted. Scott et al. (1993) used a minimum mapping unit of 100 ha and mapped at a scale of $1: 100,000$. We would argue that for many species of conscrvation concern (and especially smaller-bodied organisms like songbirds and butterflies), this scale is too coarse because microhabitats play an important role in determining suitable habitat. Gap analysis assumes that the microhabitats selected by these finer-scaled species are incorporated into the larger polygons, yet the Gap approach has not been tested at multiple scales (Flather et al. 1995). Furthermore, little prediction error or sensitivity analysis testing has been done for the Gap models. Thus, it would be advantageous to test these relationships with fine-scale mapping units (on the order of a few hectares) first.

After conducting a park-wide inventory of Glacier National Park for birds and butterflies (Debinski 1991), we began to investigate alternative methods to predict species diversity based upon landscape level habitat analysis (e.g., Maurer 1994, McLaughlin et al. 1992, Stoms and Estes 1993, Rich et al. $1992 \mathrm{a}, \mathrm{b})$. The goal was to use intensive, local ficld sampling to extrapolate species distribution 
patterns within a region. The hypothesis was that plant and animal distributions (biodiversity) could be correlated to patterns of spectral reflectance as recorded by satellite remote-sensing instruments at a scale of $30 \times 30 \mathrm{~m}$ pixels. In essence, our approach was similar to Gap analysis, but the scale was finer, and we took the opposite approach to creating a species-habitat model; we were testing the ability to find relationships between remotely sensed data and species assemblage data rather than assuming such a relationship and then predicting species distributions. We initiated this research project using remote sensing and GIS analysis of landscape to predict species distributions of grasses, forbs, shrubs, trees, birds and butterflies.

\section{$\uparrow \quad$ OBJECTIVES}

From field observations, it appeared that there were significant relationships between remotely sensed data and vegetation. For example, sagebrush Artemesia tridentata tended to be found on dry M5 and M6 sites, while sedges Carex spp. tended to be found on wet M1 and M2 plots. However, these relationships had yet to be quantified through statistical analysis. The major objective of our research was to determine the extent of the relationship between spectral reflectance patterns, as measured through remote sensing instruments, and the distribution of plant or animal species. The goal was not to do away with ground-based fieldwork, but rather to optimize and focus fieldwork by using GIS and remotely sensed data as tools for making the work more accurate and specific.

\section{$\downarrow \quad$ STUDY AREA}

The study area for this research project was a 500 sq. mile area in the northwest corner of the Greater Yellowstone Ecosystem (Fig. 1). The Landsat scene extended from Porcupine Creek to Bacon Rind Creek (north/south) and from the crest of the Madison Range to the crest of the Gallatin Range (east/west). This area was chosen for three reasons. First, it is one of the largest intact ecosystems in the continental U.S. and includes a wide range of elevation and moisture gradients. Second, lists of birds and butterfly species were available for the ecosystem (Bowser 1988, Brussard
1989). Finally, we had several years experience conducting research in the region.

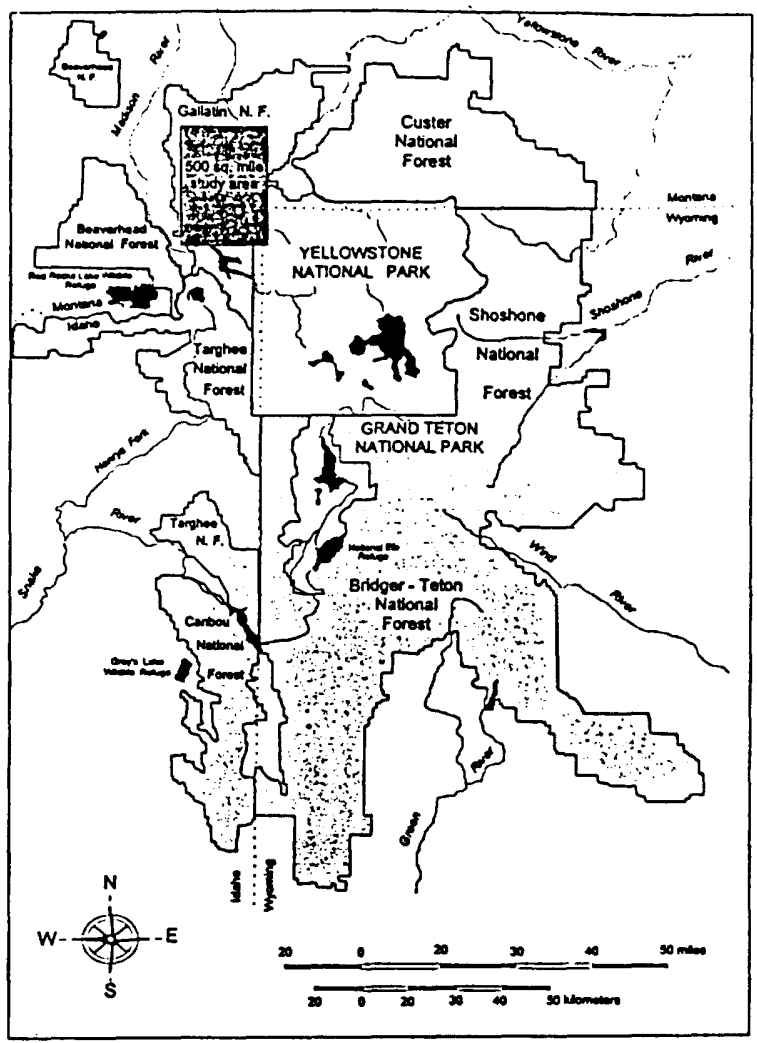

Figure 1. The Greater Yellowstone Ecosystem with study area darkened. Study area encompasses 500 sq. miles including northwest corner of Yellowstone National Park and southeast portion of the Gallatin National Forest.

\section{CRITERIA FOR CHOICE OF TAXA}

Plant species can be viewed both as a component of the species diversity as well as a component of habitat diversity as a plant community. The presence of a particular plant species at a specific site can be highly indicative of the particular microhabitat of that site. Because the plant species with dominant cover play a major role in determining what reflectance patterns are measured by satellite, we believed that it was imperative to test the relationship between the remotely sensed habitat types and the plant community. If plant species distribution patterns could not be predicted using remotely sensed data, relationships between remotely sensed data and animal taxa would be highly unlikely. Thus, a plant survey is the critical link 
between remotely sensed data, habitat, and other species distribution patterns.

Butterflies were a preferred taxa for testing the hypothesis that remotely sensed data can be used to predict species distributions. Some butterfly species are moderately host-specific, while others are highly host-specific herbivorous insects and their diversity may be correlated with underlying plant diversity. Butterflies are also well-known taxonomically and reliably identified in the field (Kremen 1992). Over one hundred different species reside in the Greater Yellowstone Ecosystem (Bowser 1988, Brussard 1989).

Birds were chosen to test the hypothesis because they are ecologically diverse and use a wide variety of food and other resources. Therefore, they reflect the condition of many aspects of the ecosystem. They also represent several trophic groups or guilds, and by having a short generation time, they exhibit quick responses to environmental change (Steele et al. 1984). Finally, they are good indicators because they are conspicuous, ubiquitous, intensively studied, and often appear to be more sensitive to environmental changes than other vertebrates (Morrison 1986). Over one hundred different species reside in the Greater Yellowstone Ecosystem.

\section{$\downarrow \quad$ METHODS}

\section{GIS AND REMOTE SENSING ANALYSIS}

The remotely sensed data included three visible, one near infrared, and two middle infrared bands. Landsat 5 Thematic Mapper (TM) data from a 31 July, 1991 scene were registered to a Universal Transverse Mercator (UTM) coordinate system using ground control points selected from maps covering the study area, and resampled to $30 \times 30 \mathrm{~m}$. Digital elevation model (DEM) data were obtained from the U.S. Geological Survey (USGS) projected to UTM coordinates, and the maps of slope, aspect, and elevation created using ERDAS GIS software. TM pixel brightness values was converted to radiance values (watts $/ \mathrm{m}^{2} / \mathrm{steradian} /$ nanometer) to account for effects of changing instruments and calibration drift. Six bands were available to describe each $30 x$ $30 \mathrm{~m}$ pixel. TM data transformations were used to extract vegetation information (i.e., Tasscled Cap,
Principal Components Analysis, and Normalized Difference Vegetation Index (NDVI)). To avoid sampling on cliffs or extremely steep slopes, areas of greater than 30 degrees slope were masked out on the Landsat data.

These remotely sensed data were then clustered into 50 spectrally distinct classes, and classified using a minimum distance classifier. Cluster classes were evaluated using U.S. Forest Service (USFS) stand survey maps, aerial photography, and personal knowledge of the study area. The 50 classes were then combined to form eleven spectrally distinct vegetation cover types. To facilitate location of study sites during fieldwork, the map was converted to vector format and plotted on translucent Mylar, allowing overlay onto a 1:24,000 scale USGS topographic maps of the study region (Fig. 2).

Five forest habitat types and six meadow habitat types were identified in the preliminary analysis. Forest types included Douglas Fir Pseudotsuga menzesii (DF), Whitebark Pine Pinus albicaulis (WB), and mixed conifer Lodgepole Pine Pinus contorta, Engleman's Spruce, Picea englemanii, and Douglas Fir of three different densities (F1-F3). Meadows ranged from Ml (sedge meadow) to M6 (dry grassland with sagebrush). We inventoried five spatially distinct examples of each of the F1-F3 and M1-M6 habitat types (nine habitat types, total sites $=45$ ).

\section{SPECIES AND HABITAT CHARACTERIZATION IN SAMPLE SITES}

Trees were sampled for species composition and cover by establishing a $100 \mathrm{~m}$ transect and surveying every tree within $3 \mathrm{~m}$ on either side of the transect line (Brower et al. 1990). Five spatially distinct areas were surveyed for each of three forest types (F1, F2, F3) during 1993. Grasses, forbs, and shrubs were also surveyed in five spatially distinct areas for each of the six meadow types during 1994. Twenty-five $1 \mathrm{~m}^{2}$ plots were established at $4 \mathrm{~m}$ intervals along a $100 \mathrm{~m}$ transect, and each plot was surveyed for total coverage on a per species basis for all grasses, forbs, and shrubs. The species cover was determined by two observers visually estimating and agreeing on the sum of the greatest spread of foliage for each species in each plot (Daubenmire 1959). In 


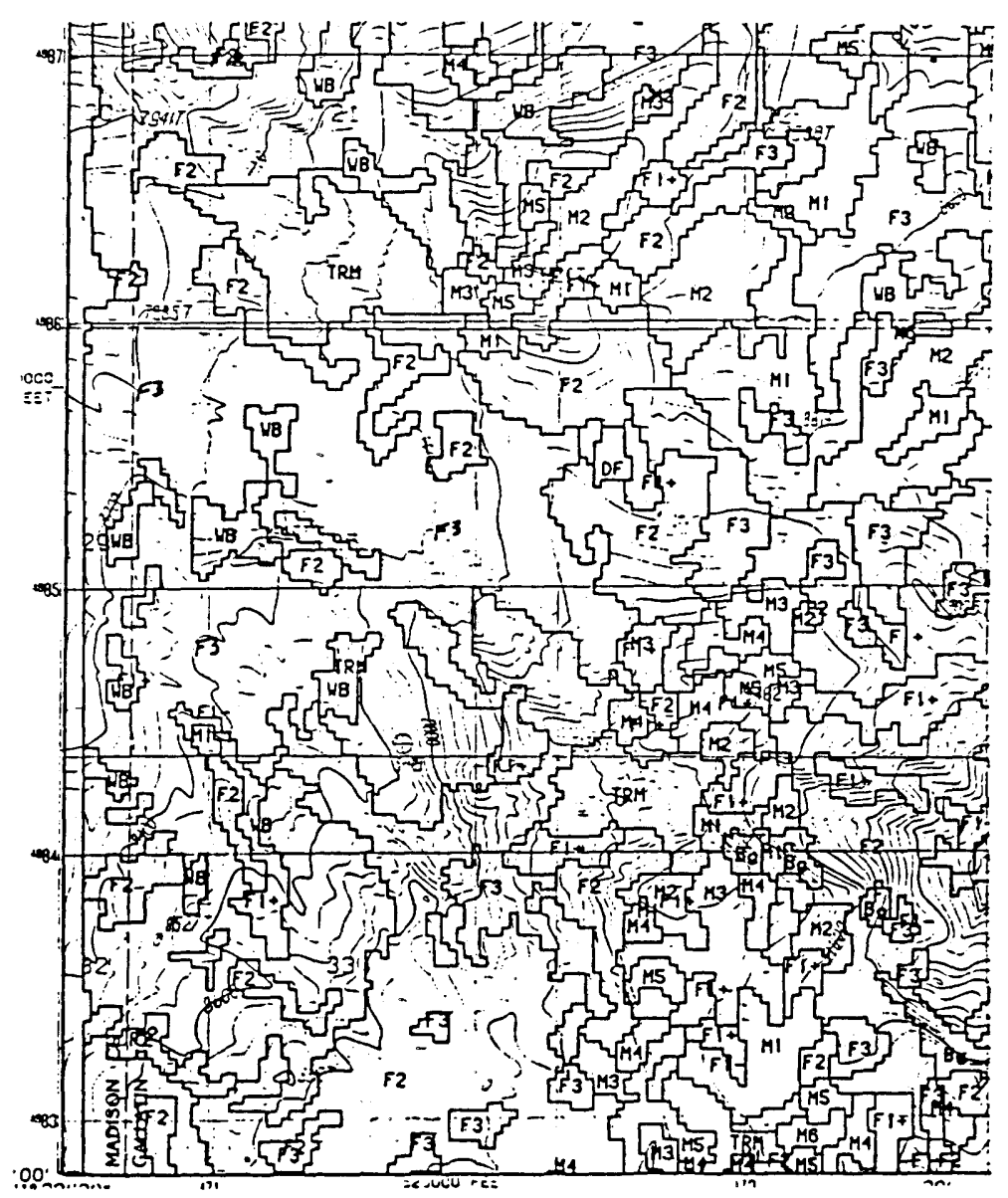

Figure 2. An example of a map of spectrally distinct vegetation cover types overlayed on a 1:24,000 scale USGS topographic map. Habitat types are based upon remote sensing cluster analyss followed by ground-truthing with USFS stand survey maps and aerial photos. Codes are as follows: Mixed conifer forest Pinus contorta, picea englemanii, and Pseudotsuga menzezii of high density (F3), lower density (F2), and fairly sparse forest (F1), Pseudotsuga menzezii forest (DF), Pinus albicaulis forest (WB), hydric/lush meadow (M1), decreasing moisture gradient of meadows (M2-M4), moist sagebrush/cinquefoil meadow (MS), and xeric, mostly dry sagebrush shrubland (M6) tallus (TRM), and background/steep slopes (Bg).

some groups, where species identification was problematic, species were clumped within the genus to calculate a total cover for the genus rather than the species. These genera were: Agoseris, Agropyron, Agrostis, Arabis, Arenaria, Aster, Astragalus, Bromus, Carex, Corydalis, Crepis,Cryptantha, Draba, Erigeron, Festuca, Juncus, Oxytropus, Poa, Potentilla, Ranunculus, Senecio, Solidago, and Senecio.

Presence/absence data were collected for butterflies and birds during 1993, employing previously developed methods (Debinski 1991, Debinski and Brussard 1992). Birds were surveyed from 0530-1000 hrs. in thirty-five sites comprising three forest types (F1-F3) and six meadow types (M1 - M6). Auditory and visual surveys were conducted using four observers (two groups of two) moving systematically through the $100 \times 100 \mathrm{~m}$ plots for 45 minutes. Bird surveys were repeated three times at each site during the course of a summer. Butterflies were surveyed from 1000-1630 hrs. in 23 meadows of type M1-M6. Butterflies were censused by netting and releasing for 20 minutes in three randomly selected $50 \times 50 \mathrm{~m}$ subplots within each larger $100 \times$ $100 \mathrm{~m}$ plot. Sites of this scale were chosen to minimize habitat heterogeneity. Sampling for butterflies was repeated at least two, and preferrably three times during the course of the 1993 field season. 


\section{DEVELOPING AND TESTING THE MODELS}

Stepwise discrminant analysis, ANOVA and logistic regression wcre used to test for relationships between species frequencies patterns and remotely sensed habitat types. These analyses were used to 1) determine which species had significant relationships with the remotely sensed habitat types, 2) determine whether the size classes (DBH) of trees differed among remotely sensed forest types, and 3) determine whether hotspots of species diversity corresponded among taxonomic groups. Each taxonomic group was tested separately for relationships with remotely sensed data, and subgroups (e.g. shrubs, forbs, grasses) were also analyzed. Total coverage for all vegetation plots within a transect was standardized to $100 \%$. Stepwise discriminant analysis was conducted using a subset of the data, excluding species which occured in less than 2 percent coverage in every transect (total species $=80$ ).

Multivariate analysis of the bird and butterfly data was conducted by using a modified presence/absence matrix which weighted the number of species occurrences relative to the number of times a site was surveyed. This data set provided more information than a simple presence/absence matrix. The number of occurrences of each species per site was summed over all the samples, rather than merely indicating whether or not the species has ever been seen at that site. In order to adjust for inconsistencies in sampling effort, each species/site combination was scored as $p_{i j}=m_{i j} / n_{j}$, where $m_{i j}$ is the number of occurrences for species $i$, and $n_{j}$ is the total number of samples taken at site $j$.

\section{$\uparrow \quad$ RESUltS}

The analysis of the 1993 and 1994 field data showed several important relationships between remotely sensed habitat types and species distribution patterns of vegetation, birds, and butterflies. Field surveys in 1993 validated the vegetation density, composition, and moisture gradients expected from satellite data interpretation. Field data supported the expected gradient of increasing forest density from $\mathrm{F} 1$ to $\mathrm{F} 3$ forests. In addition, we observed that $\mathrm{F} 3$ forests tended to be located on stcep, north-facing slopes. Discriminant analysis was used to determine whether F1, F2, and F3 forests differed significantly with respect to tree species composition and DBH (diameter at breast height). The same species were found over all forest types, but the relative abundance of each species and DBH were significant in discriminating between forest types. Fl forests tended to have fewer trees $\left(0.034\right.$ trees $\left./ \mathrm{m}^{2}\right)$ with larger DBH $($ mean $=10.61 \mathrm{~cm})$, while $F 2$ and $F 3$ forests had more trees $(0.07$ and $\left.0.067 \mathrm{trees} / \mathrm{m}^{2}\right)$ and larger DBH values [(F2 mean $\mathrm{DBH}=8.59 \mathrm{~cm}, \mathrm{~F} 3$ mean $\mathrm{DBH}=7.35 \mathrm{~cm} \quad(\mathrm{~F}=7.971$ for $\mathrm{DBH}$; $\mathrm{df}=2,502, \mathrm{a}=0.05$, table value $\mathrm{F}=$ 3.07)]. Fl forests were composed of a combination $f$ Pinus contorta, Picea englemanii, and Pseudotsuga menzezii while F2 forests were primarily Picea englemanii and Pseudotsuga menzezii with less Pinus contorta. F3 forests were primarily composed of Picea englemanii with less Pinus contorta and Pseudotsuga menzezii $(\mathrm{F}=21.73, \mathrm{df}=2,502, \mathrm{a}=$ 0.05 , table value $F=3.07$ ).

Analysis of the grass, forb, and shrub cover data revealed several strong relationships between species distribution patterns and remotely sensed meadow types. Ground-truth data confirmed the moisture gradient for meadows predicted from the satellite data. M1 and M2 meadows were sedge marshes with some standing water. M3 meadows were characterized by willow thickets and were located near streams. M4 meadows were of medium moisture with cinquefoil and mixed herbaceous vegetation, while M5 meadows had a mixture of sagebrush and herbaceous vegetation. M6 meadows were characteristically south-facing, rocky, and covered with sagebrush. One hundred and fortythree species (or species groups) of plants were observed in 1994 on 30 meadow sites. Twenty-two of these species were statistically significant in distinguishing among remotely sensed habitat types. Several of these species showed clear trends in total coverage which either increased or decreased around a specific habitat type (Table 1).

A total of 74 bird species and 38 butterfly species were observed during the surveys (Tables 2 and 3). Several species of birds exhibited a habitat preference (Tables 2 and 4). For example, a stepwise discriminant analysis of species distribution 


\begin{tabular}{|c|c|c|c|c|c|c|}
\hline Species & $\underline{\text { M1 }}$ & $\underline{\mathrm{M}} 2$ & $\underline{\mathrm{M} 3}$ & $\underline{\text { M4 }}$ & $\underline{\text { MS }}$ & $\underline{\text { M6 }}$ \\
\hline Festuca sp. & 3.9 & 10.5 & 29.8 & 62.4 & 105.6 & 125.2 \\
\hline Aster integrifolius & 56.0 & 24.7 & 8.7 & 2.0 & 0.1 & 0.2 \\
\hline Thalictrum dasycarpum & 2.1 & 0.4 & 2.4 & 0.0 & 0.0 & 0.0 \\
\hline Geum triflorum & 0.5 & 4.6 & 10.2 & 28.2 & 21.7 & 0.0 \\
\hline Polemonium pulcherrimum & 4.3 & 1.2 & 0.6 & 0.0 & 0.0 & 0.0 \\
\hline Agrostis scabra & 1.5 & 0.7 & 0.1 & 0.2 & 7.2 & 0.0 \\
\hline Aster campestris & 0.0 & 8.5 & 7.0 & 1.2 & 3.1 & 12.8 \\
\hline Arctostaphylos uva-ursi & 1.0 & .23 & 4.1 & 0.0 & 0.0 & 0.0 \\
\hline Trifolium longipes & 6.0 & 24.8 & 0.4 & 1.4 & 1.9 & 0.0 \\
\hline Salix Wolfii & 29.0 & 34.8 & 0.0 & 0.0 & 0.0 & 0.0 \\
\hline Bromus sp. & 14.4 & 10.5 & 11.5 & 18.6 & 15.8 & 3.3 \\
\hline Eriogonum umbellatum & 0.0 & 0.1 & 0.3 & 2.7 & 6.8 & 1.6 \\
\hline Muhlenbergia richardsonis & 0.0 & 10.1 & 0.2 & 0.0 & 0.0 & 0.0 \\
\hline Equisetum hyemale & 7.9 & 2.1 & 0.2 & 0.0 & 0.0 & 0.0 \\
\hline Salix bebbiana & 6.8 & 0.0 & 29.7 & 0.0 & 0.0 & 0.0 \\
\hline Lomatium triternatum & 1.2 & 4.1 & 2.6 & 0.0 & 0.0 & 0.0 \\
\hline Phleum pratense & 13.8 & 22.1 & 8.4 & 18.2 & 15.8 & 0.6 \\
\hline Senecio sp. & 17.8 & 4.2 & 0.1 & 0.3 & 6.1 & 0.1 \\
\hline Symphoricarpos albus & 0.0 & 0.0 & 6.1 & 0.0 & 0.0 & 0.0 \\
\hline Fragaria virginiana & 30.5 & 26.1 & 34.0 & 25.4 & 16.5 & 0.0 \\
\hline Danthonia intermedia & 0.0 & 0.2 & 0.5 & 0.5 & 12.2 & 0.0 \\
\hline Arenaria hookeri & 0.0 & 0.0 & 1.4 & 0.3 & 3.0 & 3.8 \\
\hline
\end{tabular}

patterns by habitat showed seven bird species had significantly different frequencies in forest versus meadow habitats: Mountain chickadee Parus atricapillus, Brown creeper Certhis familiaris, American crow Corvus brachyrhynchos, Orangecrowned warbler Vermivora celata, Hermit thrush Hylocichla guttata, American robin Turdus migratorius, and Song sparrow Melospiza melodia.

All of these species except tht Song sparrow showed a preferrence for forest. When habitats were clumped into broad categories, (M1-M2, M3-M4, $\mathrm{M} 5-\mathrm{M} 6$, and $\mathrm{F} 1-\mathrm{F} 3$ ) preferences were as follows, Mountain chickadee (F1-F3), Song sparrow (M1M2), Rufous sided towhee Pipilo erythrophthalmus (M1-M2), Dark-eyed junco Junco hyemalis (F1-F3), Violet-green swallow Tachycineta thalassina (M5M6), and Hairy woodpecker Dendrocopos villosus (M3-M4). Significant differences among forest preference were as follows: American robin (F3), Red-breasted nuthatch Sitta canadensis (F3), Rubycrowned kinglet Regulus calendula (F1) and Song sparrow (M1-M2)

Several butterfly species were found only in hydric or xeric habitat groups (Table 3 ), but only two species showed significant relationships with one specific habitat type in stepwise discriminant analysis $(\alpha=0.5)$. Colias pelidne was significantly correlated with M6 meadows and was found only in M6 meadows, while Plebejus icariodes was found in all meadows, but showed a preference for drier meadows. Six butterfly species showed a habitat preference for dry meadows (e.g. F2, M5-M6), or mesic to xeric meadows (M3-M6). Five species were found solely in M3 meadows, and one species Boloria frigga was found only in hydric meadows (M1-M3). Four species were found in all meadow types.

Species richness was highest for plants (forbs, grasses, and shrubs), birds and butterflies in M3 meadows (Table 5). M3 meadows supported a strikingly higher diversity of birds (41 species) relative to all other meadow and forest habitat types. M3, M5, and M6 meadows all supported high species diversity of butterflies $(24,23$, and 23 species respectively). Forbs, grasses, and shrubs showed a less striking difference in diversity among meadow types, but M3 meadows had the highest species richness. 

incorporate a density gradient (F1, low density to $F$, high density.

Vermivora celata

Dendroica petechia

Dendroica coronata

Dendroica townsendi

Oporornis tolmiei

Geothlypis trichas

Wilsonia pusilla

Euphagus cyanocephalus

Molothrus ater

Piranga ludoviciana

Passerina amoena

Pheucticus melanocephalus

Carpodacus cassinii

Pinicola enucleator

Carduelis pinus

Loxia curvirostra

Chlorura chlorura

Passerculus sandwichensis

Melospiza melodia

Pooecetes gramineus

Junco hyemlalis

Tachycineta bicolor

Spizella passerina

Zonotrichia leucophrys

Corvus brachyrhynchos

Perisoreus canadensis

Cyanocitta stelleri

Pica pica

Nucifraga columbiana

Parus atricapillus

Parus gambeli

Sitta canadensis

Certhia americana

Troglodytes aedon

Turdus migratorius

Catharus guttatus

Catharus ustalatus

Catharus fucenscens

Sialia currucoides

Myadestes townsendi

Regulus satrapa

Regulus calendula

Stirnus vulgaris

Vireo gilvus

Stellula calliope

Coloptes auratus

Sphyrapicus ruber

Sphyrapicus varius

Sphyrapicus thyroideus

Picoides villosus

Picoides pubescens

Tyrannus verticalis

Sayornis saya

Empidonax traillii

Empidonax hammondii

Empidonax oberholseri

Empidonax minimus

Contopus sordidulus

Contopus borealis

Tachycineta thalassina

Iridoprocne bicolor

Riparia riparia

Stelgidopteryx ruficollis

Petrochelidon pyrrhonoto

\begin{tabular}{|c|c|c|c|c|c|c|c|c|}
\hline M1 & M2 & M3 & M4 & M5 & M6 & F1 & F2 & F3 \\
\hline & & $X$ & & & & & $\mathbf{X}$ & \\
\hline & & $\mathbf{x}$ & & & & & $\mathbf{x}$ & \\
\hline & & $\mathbf{X}$ & $\mathbf{X}$ & $\mathbf{X}$ & & $\mathbf{x}$ & $\mathbf{X}$ & $\mathbf{X}$ \\
\hline & & $\mathbf{X}$ & & & & & $\mathbf{x}$ & $\mathbf{X}$ \\
\hline & & $\mathbf{X}$ & & & & & $\mathbf{X}$ & \\
\hline & $\mathbf{X}$ & $\mathbf{X}$ & & & & $\mathbf{X}$ & & \\
\hline \multirow{11}{*}{$\mathbf{X}$} & & & & & & & & \\
\hline & $\mathbf{X}$ & & $\mathbf{X}$ & $\mathbf{X}$ & $\mathbf{x}$ & & & \\
\hline & & $\mathbf{X}$ & & & & & $\mathbf{x}$ & \\
\hline & & $\mathbf{X}$ & & & & $\mathbf{X}$ & $\mathbf{X}$ & $\mathbf{X}$ \\
\hline & & $\mathbf{X}$ & & & & & & \\
\hline & & & & & & & & $\mathbf{X}$ \\
\hline & & $\mathbf{X}$ & & & $\mathbf{x}$ & $\begin{array}{l}\mathbf{X} \\
\mathbf{X}\end{array}$ & $\mathbf{X}$ & \\
\hline & & $\mathbf{X}$ & & & & $\mathbf{x}$ & $\mathbf{x}$ & $\mathbf{X}$ \\
\hline & & $\mathbf{X}$ & 。 & & & & & $\mathbf{X}$ \\
\hline & $\mathbf{x}$ & $\mathbf{x}$ & & $\mathbf{x}$ & $\mathbf{x}$ & & & \\
\hline & $\mathbf{X}$ & & $x$ & & & & & \\
\hline \multirow[t]{45}{*}{$\mathbf{X}$} & $\mathbf{X}$ & $\mathbf{X}$ & $\mathbf{X}$ & $\mathbf{X}$ & $\mathrm{X}$ & $\mathbf{x}$ & $\mathbf{X}$ & \\
\hline & $X$ & $X$ & $\mathbf{X}$ & $\mathbf{X}$ & $\mathbf{X}$ & & & \\
\hline & & $\mathbf{X}$ & $\mathbf{X}$ & $X$ & $\mathbf{X}$ & $\mathbf{x}$ & $\mathbf{X}$ & $\mathbf{X}$ \\
\hline & & $\mathbf{X}$ & & & & & $\mathbf{x}$ & \\
\hline & $\mathbf{X}$ & $\mathbf{X}$ & $X$ & & $\mathbf{X}$ & $\mathbf{X}$ & $\mathbf{X}$ & $\mathbf{X}$ \\
\hline & $\mathbf{X}$ & $\mathbf{X}$ & $\mathbf{X}$ & $\mathbf{X}$ & $\mathbf{X}$ & $\mathbf{X}$ & $\mathbf{X}$ & $\mathbf{X}$ \\
\hline & & 。 & $\mathbf{X}$ & & & $\mathbf{X}$ & $\mathbf{X}$ & $\mathbf{X}$ \\
\hline & & & $\mathbf{X}$ & & & $\mathbf{X}$ & $\mathbf{X}$ & \\
\hline & & & & & $\mathbf{X}$ & & $\mathbf{X}$ & \\
\hline & & & & & $\mathbf{X}$ & & & \\
\hline & & $\mathbf{X}$ & $\mathbf{X}$ & & & $\mathbf{X}$ & $\mathbf{X}$ & $\mathbf{X}$ \\
\hline & & $\mathbf{X}$ & & & & $\mathbf{X}$ & $X$ & $\mathbf{X}$ \\
\hline & & $\mathbf{X}$ & $\mathbf{x}$ & & & $\mathbf{x}$ & $\mathbf{X}$ & $\mathbf{X}$ \\
\hline & & $x$ & & & & $\mathbf{X}$ & $\mathbf{X}$ & $\mathbf{X}$ \\
\hline & & & & & & $\mathbf{X}$ & $\mathbf{X}$ & \\
\hline & & $\mathbf{X}$ & & & & & & \\
\hline & $\mathbf{X}$ & $\mathbf{X}$ & $\mathbf{X}$ & $X$ & $\mathbf{X}$ & $\mathbf{X}$ & $\mathbf{X}$ & $\mathbf{X}$ \\
\hline & & & & & & $\mathbf{X}$ & $\mathbf{X}$ & $\mathbf{X}$ \\
\hline & & & & & & $\mathbf{X}$ & $\mathbf{X}$ & $\mathbf{x}$ \\
\hline & & & & & & $\mathbf{X}$ & & \\
\hline & $\mathbf{X}$ & $\mathbf{X}$ & & $\mathbf{x}$ & $\mathbf{X}$ & & & \\
\hline & & $\mathbf{X}$ & $\mathbf{x}$ & $\mathbf{X}$ & $\mathbf{X}$ & & & \\
\hline & & $x$ & & & & $\mathbf{x}$ & $x$ & $\mathbf{X}$ \\
\hline & & $\mathbf{X}$ & & & $\mathbf{X}$ & $\mathbf{X}$ & $\mathbf{X}$ & $\mathbf{X}$ \\
\hline & & $\mathbf{X}$ & & & & $\mathbf{X}$ & $\mathbf{X}$ & $\mathbf{X}$ \\
\hline & $\mathbf{X}$ & $\mathrm{X}$ & $\mathbf{X}$ & & & $\mathbf{X}$ & $\mathbf{X}$ & $\mathbf{X}$ \\
\hline & & $\mathbf{X}$ & & & $\mathbf{X}$ & $\mathbf{x}$ & $\mathbf{X}$ & $\mathbf{X}$ \\
\hline & $\mathbf{X}$ & $\mathrm{X}$ & & & $\mathbf{X}$ & $\mathbf{X}$ & $X$ & $\mathbf{X}$ \\
\hline & & & & & & $\mathbf{X}$ & & \\
\hline & & & & & & $\mathbf{X}$ & & \\
\hline & & & & & & $\mathbf{X}$ & & \\
\hline & & $\mathrm{X}$ & & & & & & \\
\hline & & $\mathbf{X}$ & & & & - & & $\mathbf{X}$ \\
\hline & & & & & & $\mathbf{x}$ & & \\
\hline & & $x$ & & & & & & \\
\hline & & $\mathbf{X}$ & & & & & & \\
\hline & & $\mathbf{X}$ & & & & & & \\
\hline & $\mathbf{X}$ & $\mathbf{X}$ & & & & & & \\
\hline & & & & & & & $\mathbf{X}$ & \\
\hline & $\mathbf{x}$ & $\mathbf{X}$ & & & & & $\mathbf{X}$ & \\
\hline & & & & & $\mathbf{X}$ & & $\mathbf{X}$ & \\
\hline & $x$ & $\mathbf{X}$ & $\mathbf{X}$ & $\mathbf{X}$ & $\mathbf{X}$ & & & \\
\hline & $\mathbf{X}$ & & & & & & & \\
\hline & $\mathbf{X}$ & & $\mathbf{X}$ & & $\mathbf{X}$ & & & \\
\hline & & $\mathbf{x}$ & $\mathbf{X}$ & & $\mathbf{X}$ & & & \\
\hline
\end{tabular}




\begin{tabular}{|c|c|c|c|c|c|c|}
\hline & M1 & M2 & M3 & $\mathbf{M} 4$ & M5 & M6 \\
\hline Parnassius pheobus & & & & & $\mathbf{X}$ & $\mathbf{X}$ \\
\hline Parnassius proto & $\mathbf{X}$ & $\mathbf{x}$ & $\mathbf{x}$ & $\mathbf{X}$ & $\mathbf{X}$ & \\
\hline Pieris napi & $\mathbf{x}$ & $\mathbf{X}$ & $\mathbf{X}$ & $\mathbf{X}$ & $\mathbf{X}$ & $\mathbf{x}$ \\
\hline Colias interior & & & & & $\mathbf{X}$ & $\mathbf{x}$ \\
\hline Colias philodice & & & & & & $\mathbf{x}$ \\
\hline Colias eurytheme & & & & $\mathbf{x}$ & & \\
\hline Colias pelidne & & & & & & $\mathbf{X}$ \\
\hline Anthocharis sara & & & $\mathbf{X}$ & $\mathbf{X}$ & $\mathbf{X}$ & $\mathbf{X}$ \\
\hline Euchloe ausonide & $\mathbf{x}$ & $\mathbf{X}$ & $\mathbf{X}$ & $\mathbf{X}$ & $\mathbf{X}$ & $\mathbf{X}$ \\
\hline Lyceana cupreus & & & & $\mathbf{X}$ & $\mathbf{X}$ & \\
\hline Gaeides xanthoides & & & $\mathbf{X}$ & & $\mathbf{X}$ & $\mathbf{x}$ \\
\hline Lyceana heteronea & & $\mathbf{X}$ & & & $\mathbf{X}$ & $\mathbf{x}$ \\
\hline Lycaena helloides & & $\mathbf{x}$ & $\mathbf{X}$ & & & $\mathbf{x}$ \\
\hline Lycaena mariposa & & & $\mathbf{X}$ & & & \\
\hline Plebejus saepiolus & & $\mathbf{x}$ & $\mathbf{x}$ & $\mathbf{X}$ & $\mathbf{x}$ & $\mathbf{X}$ \\
\hline Plebejus icariodes & & $\mathbf{X}$ & $\mathbf{X}$ & $\mathbf{X}$ & $\mathbf{X}$ & $\mathbf{X}$ \\
\hline Plebejus acmon & & & $\mathbf{x}$. & $\mathbf{X}$ & $\mathbf{X}$ & $\mathbf{X}$ \\
\hline Plebejus glandon & & & $\mathbf{X}$ & & & \\
\hline Euphilotes enoptes & & & $\mathbf{X}$ & & & \\
\hline Vanessa cardui & $\mathbf{X}$ & $\mathbf{X}$ & $\mathbf{X}$ & $\mathbf{X}$ & $\mathbf{X}$ & $\mathbf{x}$ \\
\hline Nymphalis milberti & & $\mathbf{X}$ & & $\mathbf{X}$ & & \\
\hline Polygonia faunus & & $\mathbf{X}$ & & & & \\
\hline Chlosyne palla & & & $\mathbf{x}$ & & & \\
\hline Phyciodes tharos & & $\mathbf{X}$ & & & & \\
\hline Physiodes campestris & & $\mathbf{x}$ & $\mathbf{x}$ & $\mathbf{X}$ & $\mathbf{x}$ & $\mathbf{X}$ \\
\hline Boloria frigga & $\mathbf{x}$ & $\mathbf{x}$ & $\mathbf{x}$ & & & \\
\hline Boloria selene & & & $\mathbf{x}$ & & & \\
\hline Boloria epithore & & $\mathbf{X}$ & $\mathbf{X}$ & $\mathbf{X}$ & $\mathbf{X}$ & $\mathbf{X}$ \\
\hline Speyeria atlantis & & $\mathbf{X}$ & $\mathbf{X}$ & & $\mathbf{X}$ & $\mathbf{X}$ \\
\hline Speyeria mormonia & & & $\mathbf{X}$ & $\mathbf{X}$ & $\mathbf{X}$ & $\mathbf{X}$ \\
\hline Cenonympha hadenii & & $\mathbf{X}$ & $\mathbf{X}$ & $\mathbf{X}$ & $\mathbf{x}$ & $\mathbf{X}$ \\
\hline Cenonympha inornata & & $\mathbf{x}$ & $\mathbf{x}$ & $\mathbf{x}$ & $\mathbf{X}$ & $\mathbf{x}$ \\
\hline Cercyonis oetus & & & $\mathbf{X}$ & & $\mathbf{X}$ & $\mathbf{X}$ \\
\hline Oeneis uhlerii & & & & & $\mathbf{X}$ & $\mathbf{X}$ \\
\hline Oeneis chryxus & & & & & $\mathbf{x}$ & \\
\hline Erebia epipsodea & $\mathbf{X}$ & $\mathbf{X}$ & $\mathbf{x}$ & $\mathbf{x}$ & $\mathbf{x}$ & $\mathbf{X}$ \\
\hline
\end{tabular}

\section{$\downarrow$ DISCUSSION}

The goal of this research was to explore new uses of remotely sensed data as predictors of plant and animal species locations and to determine the correlation in species richness patterns among taxa. We expected spectral reflectance patterns to be relatively good predictors of vegetation. This expectation was met by our data analysis. Tree species and mean DBH were both significantly related to remotely sensed forest habitat types. Twenty-two species of grasses and forbs were significant in discriminating among meadow types. Festuca sp., Aster campestris, and Arenaria hookeri were associated with the driest meadows, Agrostis scabra, Erigonum umbellatum, and Danthonia intermedia with M5's, Geum triflorum, and Bromus sp. with M4's, Thalictrum dasycarpum, Arctostaphylos uva-ursi, Symphoricarpos albus, Salix bebbiana and Fragaria virginiana with M3's, Triflolium longipes, Salix wolfii, Muhlenbergia richardsonis, Lomatium tritenatum, and Phleum pratense with wetter M2's, and Aster integrifolius, Polemonium pulcherrimum, Equisetum hyemale, and Senecio sp. with the wettest M1 meadows. All of these relationships make sense given known habitat preferrence of these species.

The next step was to determine whether spectral reflectance patterns could be correlated to distributions of selected animal taxa. Several species of birds and butterflies were associated with one or more remotely sensed habitat types. Statistical analysis revealed several significant species/habitat relationships. Seven bird species were significant in distinguishing between meadow and forest habitats. Six bird species were significant in distinguishing among finer gradations of habitat subsets (e.g., forests, hydric, mesic, and xeric meadows). Four bird species were significant in distinguishing among forest habitats. All of these species/habitat relationships make sense given known habitat preferences, except the Hairy woodpecker in M3-M4. 
Table 4. Total occurrence of bird species significantly related to one habitat type based upon results of stepwise discriminant analysis. Species are listed in order of inclusion in stepwise discriminant analysis.

Meadow versus Forest Categorization (alpha $=0.05$ )

Species

Mountain chickadee

Brown creeper

American crow

Orange-crowned warbler

Hermit thrush

American robin

Song sparrow

$\begin{array}{lll}\text { Meadow } & & \text { Forest } \\ .030 & & .482 \\ .000 & & .130 \\ .015 & & .148 \\ .015 & & .019 \\ .000 & & .130 \\ .394 & & .648 \\ .561 & & .037\end{array}$

Clumped Habitat Categorization (alpha $=0.05$ )

Species

Mountain chickadee

Song sparrow

Rufous-sided towhee

Dark-eyed junco

Violet green swallow

Hairy woodpecker
$\underline{\mathrm{M} 1-\mathrm{M} 2}$

.000

.800

.067

.133

.000

.000

\section{$\underline{\mathrm{M} 3-\mathrm{M} 4}$}

.067

.600

.000

.483

.000

.033

F2

.528

500

.667
F1

.548

Red-breasted nuthatch

Ruby-crowned kinglet

Song sparrow
714

.048

\begin{tabular}{|c|c|}
\hline M5-M6 & $\mathrm{Fl}-\mathrm{F} 3$ \\
\hline .000 & .482 \\
\hline 333 & .037 \\
\hline .000 & .000 \\
\hline .238 & .926 \\
\hline .095 & .000 \\
\hline .000 & .000 \\
\hline
\end{tabular}

F3

.933

800

.600

.000

Table 5. Species Richness in Remotely Sensed Meadows of the Greater Yellowstone Ecosystem

$\begin{array}{lccccccccc} & \text { M1 } & \text { M2 } & \text { M3 } & \text { M4 } & \text { M5 } & \text { M6 } & \text { F1 } & \text { F2 } & \text { F3 } \\ \text { Grass, forbs, shrubs } & 83 & 79 & 95 & 82 & 72 & 61 & & & \\ \text { Butterflies } & & 6 & 18 & 24 & 17 & 23 & 23 & & \\ \text { Birds } & & 2 & 17 & 41 & 17 & 10 & 18 & 30 & 32\end{array}$


However, this can be explained by the fact that many of the moist meadows had aspen Populus tremuloides stands on their edges. The woodpeckers were using the aspen for nesting, and the meadows for foraging. Two of the 38 butterfly species showed statistically significant differences in frequency among meadow types. However, several other species showed trends in this direction. Species richness patterns did show similar trends across taxonomic groups. M3 meadows supported the highest species richness for birds, butterflies, and vegetation (shrubs, grasses, and forbs). It was not possible to compare species richness among forest sites due to limitations in taxa sampled.

Plants were more highly correlated with remotely sensed habitat types than were animals. This can be explained by several factors: (1) the remote sensing image is actually reflecting the presence of these plants on the ground, (2) plant data was measured in terms of coverage and animal data was measured as presence or absence, (3) plants are stationary and fixed on the landscape, whereas animals are moving through the landscape matrix and may or may not be present when the data are being collected.

The lack of significant relationships between butterflies and remote sensing habitat types may also be due to a limited data set. 1993 was an extremely wet and cold summer; some butterfly sampling sites were only surveyed twice due to poor weather which limited sampling of butterflies. Finally, one would not expect all species to be significantly correlated with one remotely sensed habitat type. Species that were found in only a few sites do not provide enough data for rigorous statistical relationships. Similarly, species found in a range of habitat types (e.g. M1-M3) will not demonstrate a statistical correlation with one specific habitat type using discriminant analysis. Thus, in order to build predictive models of species habitat relationships using remote sensing and GIS methods, a species must be common enough and habitat specific enough to exhibit a significant relationship with one or more remotely sensed habitat types.

Large-scale application of this technique could be particularly valuable for finding new locations of rare species with known habitat associations (e.g., a species restricted to dense forest or wet meadows). Our methodology may make it possible to survey a small fraction of the ecosystem (c.g., 5\%) to find the specific habitat of rare species, such as the butterfly Euphydryas gillettii. E. gillettii is a specialist on black twinberry Lonicera involucrata, is found in mesic meadows, and its populations are declining (Debinski 1994b). Our model could also be valuable in monitoring the effects of global climate change on certain species distributions (e.g., Hobbs 1990), however, the limitations of these technologies must be recognized. Extremely rare species and species that are not habitat specific must be monitored using more field intensive methods.

\section{ACKNOWLEDGEMENTS}

This research was supported by grants from the University of Wyoming National Park Service Research Center and the University of Kansas' General Research Fund and Panorama Society. Alan Vandiver, Ron Krager, and Nancy Hallstrom of the Gallatin National Forest provided data, maps of the area, and housing. We thank James Pritchard, Liesl Kelly, Camille King, Katie Horst, Amy Trainer, Rebecca Hurst, and Paul Rich, for assistance in the field, and Susan White, and Mark Jakubauskas for assistance with data analysis.

\section{Literature Cited}

Armstrong, D.M. 1972. Distribution of mammals in Colorado. Univ. Kansas, Mus. Nat. Hist., Monogr. No.3:1-415.

Baker, R.H. 1956. Mammals of Coahuila, Mexico. Univ. Kansas, Mus. Nat. Hist., Monogr. No.9(7):125-335.

Bowser, G. 1988. Phenology of butterflies' Lepidoptera - Rhopalocera adult food plants in Yellowstone National Park. Master's Thesis, University of Vermont.

Brower, J.E., J.H. Zar, and C.N. von Ende. 1990. Field and Laboratory Methods for General Ecology, 3rd Edition. W.C. Brown Publishers, Dubuque, IA. 
Brussard, P.F. 1989. Butterflies of the Greater Yellowstone Ecosystem. in: T. Clark et al. Rare, Sensitive, and Threatened Species of the Greater Yellowstone Ecosystem. Northern Rockies Conservation Cooperative, Montana Natural Heritage Program, The Nature Conservancy, and Mountain West Environmental Services. Jackson Hole, WY. pp. 28-32.

Daubenmire, R.F. 1959. Canopy coverage method of vegetation analysis. Northwest Science $33: 43-64$

Davis, F.W., D.M. Stoms, J.E. Estes, J. Scepan, and J.M. Scott. 1990. An information systems approach to the preservation of biologicaldiversity. International Journal of Geographical Information Systems 4(1):5578.

Debinski, D.M. 1991. Inventory and Monitoring of Biodiversity: An assessment of methods and a case study of Glacier National Park, MT. Montana State University Ph.D. dissertation.

Debinski, D.M. 1994a. A remote sensing and GISbased model of habitat as a predictor of biodiversity. Semi-annual report to the University of Wyoming National Park Service Research Center, Moran, Wyoming.

Debinski, D.M. 1994b. Genetic diversity assessment in a metapopulation of the butterfly, Euphydryas gillettii. Biological Conservation 70:25-31.

Debinski, D.M. and P.F. Brussard. 1992. Biological diversity assessment in Glacier National Park, Montana: I. Sampling design. pp. 393-407 in: D.H. McKenzie, D.E. Hyatt, and V.J. McDonald (eds.) Proceedings from the International Symposium on Ecological Indicators. Elsevier Publishing, Essex, England.

De Wulf, R.R., R.E. Goossens, J.R. MacKinnon, W.S. Cai. 1988. Remote sensing for wildlife management: Giant Panda habitat mapping from LANDSAT MSS Images. Geocarto. Intl. 3(1):41-51.
Flather, C.H., K.R. Wilson, D.J. Dean, and W.C. McComb. 1995. The national Gap Analysis Program: a review and inspection of ecological assumptions. A report to the National Council of the Paper Industry for Air and Stream Improvement, Inc.

James, F.C. 1971. Ordinations of habitat relationships among breeding birds. The Wilson Bulletin 83:215-236.

Hobbs, R.J. 1990. Remote sensing of spatial and temporal dynamics of vegetation. pp 203219 in: R.J. Hobbs and H.A. Mooney (eds.) Remote Sensing of Biosphere Functioning. Springer-Verlag, New York.

Kindscher, K. 1994. Rockefeller Prairie: a case study of plant guild classification of a tallgrass prairie. 13th North American Prairie Conference Proceedings, Windsor, Ontario.

Kindscher, K. and P. V. Wells. 1995. Prairic plant guilds: a multivariate analysis of prairie species based on ecological and morphological traits. Vegetatio p. 1-20.

Kolasa, J. 1989. Ecological systems in hierarchical perspective: breaks in community structure and other consequences. Ecology 70(1):3647 .

Kremen, Claire. 1992. Assessing the indicator properties of species assemblages for natural areas monitoring. Ecological Applications 2(2):203-217.

Margules, C.R. and M.P. Austin (eds). 1991. Nature Conservation: Cost Effective Biological Surveys and Data Analysis. CSIRO, Australia, 207 pp.

Maurer, B.A. 1994. Geographical Population Analysis: Tools for the Analysis of Biodiversity. Blackwell Science, Inc. 144 pp. 
McLaughlin, J.F., S.B. Weiss, P.M. Rich and D.M. Debinski. 1992. Roles of GIS in conservation. Proceedings of the Twelfth Annual ESRI User Conference, June 8-12, 1992, Palm Springs, CA. pp. 237-247.

Morrison, M.B. 1986. Bird populations as indicators of environmental change. Current Ornithology 3:429-451. Plenum Publishing Corp.

Noss, R.F. 1983. A regional landscape approach to maintain diversity. BioScience 33(11):700706.

Owen, J.G. 1990. Patterns of mammalian species richness in relation to temperature, productivity, and variance in clevation. Journal of Mammalogy 71:1-13.

Prendergast, J.R., R.M. Quinn, J.H. Lawton, B.C. Eversham, and D.W. Gibbons. 1993. Rare species, the coincidence of diversity hotspots and conservation strategies. Nature(365)335-336.

Preston, E. 1992. Synoptic national assessment of comparative risks to biological diversity and landscape types. Proposed Project Plan. US EPA, Corvallis, OR

Pyle, R.M. 1982. Butterfly eco-geography and biological conservation in Washington. Atala 8(1):1-26.

Reid, W.V. and K.R. Miller (eds). 1989. Keeping Options Alive: The Scientific Basis for Conserving Biodiversity. World Resources Institute, Washington, D.C., 129 pp.

Rich, P.M., S.B. Weiss, and D.M. Debinski. 1992a. Physiographic inventory of a tropical reserve. Proceedings of the Twelfth Annual ESRI User Conference, June 8-12, 1992 , Palm Springs, CA. pp. 197-208.

Rich, P.M., S.C. Saving, D.M. Debinski, S.B. Weiss, T.D. Sisk, and J.F. McLaughlin. 1992b. A study plan for GIS-based research for La Amistad biosphere reserve, Costa Rica. (report to the Center for Conservation Biology, Stanford University).
Saxon, E.C. 1983. Mapping the habitats of rare animals in the Tanami Wildlife Sanctuary of Central Australia: An application of satellite imagery. Biological Conservation 27:243-258

Scott, J.M., J. E. Estes, J. Scepan, F. W. Davis, and D.M. Stoms. 1990. An information systems approach to the preservation of biological diversity. In: Heit, Michael and A. Shortreid.

Gis Applications in Natural Resources. GIS World, Inc. Fort Collins, CO. p. 283 - 293.

Scott, J.M., F. W. Davis, B. Csuti, R. Noss, B. Butterfield, C. Groves, H. Anderson, S. Caicco, F.D'Erchia, T. C. Edwards Jr., J. Ulliman, R.G. Wright. 1993. Gap Analysis: A geographic approach to the protection of biological diversity. Wildlife Monographs 57:1-41.

Simpson, G.G. 1964. Species diversity of North American Recent mammals. Systematic Zoology 13:57-73.

Stcele, B.B., R.L. Bayn, Jr., and C.V. Grant. 1984. Environmental monitoring using populations of birds and small mammals: Analysis of sampling effort. Biol. Cons. 30:157-172.

Stoms, D.M. and J.E. Estes. 1993. A remote sensing research agenda for mapping and monitoring biodiversity. International Journal of Remote Sensing 14(10):18391860 .

Terborgh, J. 1970. Distribution on environmental gradients: Theory and a preliminary interpretation of distributional patterns of avifauna of the Cordillera Vilcabamba, Peru. Ecology 52(1):24-40.

Tueller, P.R. 1989. Remote sensing technology for rangeland applications. J. Wildl. Manage. $42: 442-453$

Turner, M.G. 1989. Landscape ecology: the effect of pattern on process. Annual Review of Ecology and Systematics 20:171-197. 
Urban, D.L., R.V. O'Neil, and H.H. Shugart, Jr. 1987. Landscape ecology: A hierarchical perspective can help scientists understand spatial patterns. BioScience 37(2): 119-127.
Wilson, E.O. (ed). 1988. Biodiversity. National Academy Press, Washington, D.C., 521 pp. 